\title{
Inhibition of Lipopolysaccharide-Induced Neuroinflammatory Events in Bv-2 Microglia by Chestnut Peel Extract
}

\author{
Hyun Kang \\ Department of Medical Laboratory Science, College of Health Science, Dankook University, Cheonan-si, Chungnam, 330-714, \\ Republic of Korea \\ *For correspondence: Email: hyunbio@gmail.com, hkang@dankook.ac.kr; Tel: 82-41-550-1481; Fax: 82-41-559-7934
}

Received: 14 July 2013

Revised accepted: 6 September 2014

\begin{abstract}
Purpose: To evaluate the protective effects of chestnut (Castenea cranata Siebold \& Zucc., Fagaceae) peel extract on stimulated BV-2 microglial cells as well as its anti-oxidant properties.

Methods: The ethyl acetate fraction of C.cranata peel (CCP) extract was used in the study to evaluate the anti-neuroinflammatory effects in BV-2 microglial cells. Cell viability was performed by 3-(4, 5dimethylthiazol-2-yl)-2, 5- diphenyl-tetrazolium bromide (MTT) assay. Lipopolysaccharide (LPS) is used to activate BV-2 microglia. Nitric oxide (NO) levels were measured using Griess assay. Inducible NO synthase (iNOS) expressional levels were measured by Western blot analysis. Tumor necrosis factoralpha (TNF-a) production was evaluated by enzyme-linked immunosorbent assay (ELISA). Anti-oxidant properties were evaluated by 1, 1-diphenyl-2-picryl-hydrazyl (DPPH) radical scavenging assay.

Results: LPS-activated excessive release of NO in BV-2 cells was significantly inhibited $(p<0.001$ at $100 \mu \mathrm{g} / \mathrm{mL}$ ) by CCP extract. LPS-induced excessive production of inflammatory mediator such as iNOS was also significantly attenuated by CCP extract. Further, CCP extract significantly and dose dependently inhibited the TNF- $\alpha$ levels in LPS-induced BV-2 microglial cells $(p<0.05$ at $20 \mu \mathrm{g} / \mathrm{mL}, p<$ 0.01 at $40 \mu \mathrm{g} / \mathrm{mL}$ and $p<0.001$ at 80 and $100 \mu \mathrm{g} / \mathrm{mL}$ ). CCP extract also scavenged DPPH radicals in a dose-dependent fashion ( $p<0.05$ at $0.01 \mathrm{mg} / \mathrm{mL}$ and $p<0.001$ at 0.1 and $1 \mathrm{mg} / \mathrm{mL}$ ) with an $/$ C50 value of $0.08 \mu \mathrm{g} / \mathrm{mL}$.

Conclusion: Data from this study indicate that CCP extract attenuates neuroinflammatory responses in LPS-activated BV-2 microglia by inhibiting excessive production of pro-inflammatory mediators such as NO, iNOS and TNF- $\alpha$. The strong anti-oxidant effect of CCP extract suggests that it possesses antineuroinflammatory properties.
\end{abstract}

Keywords: Castenea cranata, Chestnut peel extract, DPPH radicals, Anti-oxidant, Neuroinflammation, BV-2 microglia

Tropical Journal of Pharmaceutical Research is indexed by Science Citation Index (SciSearch), Scopus, International Pharmaceutical Abstract, Chemical Abstracts, Embase, Index Copernicus, EBSCO, African Index Medicus, JournalSeek, Journal Citation Reports/Science Edition, Directory of Open Access Journals (DOAJ), African Journal Online, Bioline International, Open-J-Gate and Pharmacy Abstracts

\section{INTRODUCTION}

Neuroinflammation mediated by microglial activation appears to play an essential role in the pathogenesis of neurodegenerative diseases [1]. It was well documented that activated microglia releases proinflammatory mediators including nitric oxide (NO), inducible NO synthase (iNOS), interleukins (IL), tumor necrosis factor-alpha (TNF- $\alpha$ ), toxic free radicals $[1,2]$ and may lead to progressive damage in a number of neurodegenerative disorders including Alzheimer's and Parkinson's disease [2,3]. It is well known that microglia can be activated by 
lipopolysaccharide (LPS) and is recognized to be a useful in vitro tool for studying neuroinflammatory mechanisms [4]. LPS-activated BV2 microglia cells enhances the production of immune-related cytotoxic factors and proinflammatory cytokines $[4,5]$. Thus, agents that reduce microglial activation and their proinflammatory responses might be considered as an important therapeutic strategy for treating neuroinflammatory disorders.

Chestnut (Castenea cranata Siebold \& Zucc.) from the family Fagaceae has been used in folk medicine in many countries for centuries and several studies have reported antioxidant, antiallergic, antidiabetic and anti-amnesic properties [6,7]. The Chestnut peel has also been used as a cosmetic material for a long time in Korea and other Asian countries. It was described as an anti-wrinkle and anti-aging agent when mixed with honey [8]. It was well documented that agents that scavenge free radicals might be beneficial in delaying the process of neurodegeneration and neuroinflammation via the antioxidant defense mechanisms [9-11]. In view of the published works that CCP possessed antioxidant and antiaging properties, in the present study we aimed to investigate whether CCP extract exhibits protective effects on LPS-activated neuroinflammatory processes in BV-2 microglial cells.

\section{EXPERIMENTAL}

\section{Plant material and extraction}

Chestnut inner skin was purchased from local market, Korea in August 2013. The material was authenticated by Prof. Jong-Bo Kim, a taxonomist at Konkuk University, Korea and a voucher specimen (CC-KU2013) was kept in laboratory herbarium, Konkuk University, Korea for future reference. To obtain the CCP extract the material was washed with running tap water and chopped into smaller pieces. It was then oven-dried at $40{ }^{\circ} \mathrm{C}$ for $48 \mathrm{~h}$, and ground to a powder using conventional mixer. The ethyl acetate fraction from the water extract of chestnut inner skin was obtained as described previously [7]. CCP powder $(200$ g) was suspended and extracted with $1 \mathrm{~L}$ of water at 70 ${ }^{\circ} \mathrm{C}$ for $2 \mathrm{~h}$ in a heating mantle. Water extracts were filtered and evaporated to dryness using a rotary vacuum evaporator. The dried material was re-dissolved in $500 \mathrm{~mL}$ of double distilled water and the solution was partitioned using a separation funnel with equal volumes of ethyl acetate. The ethyl acetate fraction obtained was concentrated in a rotary evaporator and stored at $-20{ }^{\circ} \mathrm{C}$ until use.

\section{DPPH radical scavenging activity}

The anti-oxidant activity of the CCP extract was determined using the stable radical 2, 2-diphenyl1-picrylhydrazyl (DPPH, Sigma-Aldrich, St. Louis, MO, USA). The radical scavenging capacity was evaluated by employing a reaction mixture constituted by aliquots of the CCP extract and a DPPH methanolic solution as described previously [12]. A sample solution of $60 \mu \mathrm{L}$ of each concentration of CCP extract $(0.01,0.1$ and $1 \mathrm{mg} / \mathrm{mL})$, was added to $60 \mu \mathrm{L}$ of DPPH $(60 \mu \mathrm{M})$ in methanol. After mixing vigorously for $10 \mathrm{sec}$, the mixture was then transferred to a $100 \mu \mathrm{L}$ Teflon capillary tube and the scavenging activity of each sample was measured using a JES-FA ESR spectrometer (Jeol Ltd, Tokyo, Japan). A spin adduct was measured on an ESR spectrometer exactly after $2 \mathrm{~min}$. Experimental conditions were as follows: central field, 3,475 G; modulation frequency, $100 \mathrm{kHz}$; modulation amplitude, 2 G; microwave power, $5 \mathrm{~mW}$; gain, $6.3 \times 105$, and temperature, $298 \mathrm{~K}$.

\section{Cell culture and viability assay}

BV-2 microglia cells were cultured at $37{ }^{\circ} \mathrm{C}$ in 5 $\% \mathrm{CO}_{2}$ in DMEM (Invitrogen, Carlsbad, CA, USA) supplemented with $5 \%$ FBS (Hyclone, Logan, UT, USA) and antibiotics (Invitrogen). In all experiments, cells were pre-treated with CCP extract at indicated concentrations (10 - 100 $\mu \mathrm{g} / \mathrm{mL}$ ) for $1 \mathrm{~h}$ before the addition of LPS (5 $\mu \mathrm{g} / \mathrm{mL}$, Sigma-Aldrich, St Louis, MO, USA) in serum- free DMEM. An equal volume of sterile water was added to all control treatments.

For viability assay, 3-(4, 5-dimethylthiazol-2-yl)-2, 5- diphenyl-tetrazolium bromide (MTT, SigmaAldrich, St. Louis, MO, USA) assay was used as described previously [10]. BV-2 cells were plated onto 96- well plates and exposed to CCP extract. MTT was added to each well then incubated for additional $2 \mathrm{~h}$ in dark at $37^{\circ} \mathrm{C}$. The medium was then aspirated from the wells and the blue formazan product obtained was dissolved in DMSO. The plates were analyzed at $570 \mathrm{~nm}$ using a microplate reader (Tecan Trading AG, Switzerland). Each experiment was conducted in triplicate. Percentage of cell viability was calculated using Eq 1.

Cell viability $(\%)=(\mathrm{At} / \mathrm{Au}) 100$

Where At and Au are the absorbance of extracttreated and control (untreated) samples, respectively. 


\section{Immunoblot analysis and antibodies}

Cells were washed in cold PBS three times and lysed in a buffer containing $50 \mathrm{mM}$ Tris- $\mathrm{HCl}, \mathrm{pH}$ $7.4, \quad 1 \%$ (v/v) NP-40, $0.25 \%$ sodium deoxycholate, $150 \mathrm{mM} \mathrm{NaCl}, 1 \mathrm{mM}$ EDTA, 25 $\mathrm{mM} \mathrm{NaF}, 2 \mathrm{mM} \mathrm{Na} \mathrm{VO}_{4}$ and protease inhibitor cocktail (Complete MiniTM, Roche, Mannheim, Germany) at $4{ }^{\circ} \mathrm{C}$. The lysate was clarified by centrifugation at $10,000 \mathrm{~g}$ for $20 \mathrm{~min}$ at $4{ }^{\circ} \mathrm{C}$ to remove insoluble components. Cell lysates were normalized for protein content using BCA reagent (Pierce, Rockford, IL, USA). Equal amounts of protein were loaded onto $10 \%$ PAGE gels and separated by standard SDS-PAGE procedure. Proteins were transferred to an NC membrane (S\&S, Dassel, Germany) and blocked with $5 \%$ non-fat dry milk in TBS. To detect protein expression, the blots were probed with the specific antibodies against iNOS followed by the secondary antibodies coupled to horseradish peroxidase (Bio-Rad, Herculus, CA, USA). The detection of $\beta$-actin with a specific antibody was used for an internal control. The immunoreactive proteins on the membrane were detected by chemiluminescence using the West-Save substrate (Lab-Frontier, Seoul, Korea) on X-ray film. The antibodies against iNOS and $\beta$-actin were purchased from Cell Signaling Technology INC. (Beverly, MA, USA).

\section{Nitric oxide assay}

Production of NO was assayed by measuring the levels of nitrite in the culture supernatant using colorimetric assay with Griess reagent [13]. BV-2 cells $\left(2 \times 10^{5}\right.$ cells $\left./ \mathrm{ml}\right)$ were seeded in 6 -well plates in $500 \mu$ l complete culture medium and treated with the CCP extract at indicated concentrations for $1 \mathrm{~h}$ prior stimulation with LPS $(5 \mu \mathrm{g} / \mathrm{ml})$ for $2 \mathrm{~h}$. Culture supernatant $(50 \mu \mathrm{l})$ was reacted with an equal volume of Griess reagent $(0.1 \%$ naphthylethylenediamine and $1 \%$ sulfanilamide in $5 \% \mathrm{H}_{3} \mathrm{PO}_{4}$ ) in 96-well plates at room temperature in the dark. Absorbance was determined at $540 \mathrm{~nm}$ using a microplate reader (Tecan). Nitrite concentrations were determined by extrapolation from a sodium nitrite standard curve.

\section{TNF- $\alpha$ assay}

BV-2 microglia cells $\left(1 \times 10^{5}\right.$ cells/well) were cultured on 96-well plates and treated with the CCP extract at indicated concentrations for $1 \mathrm{~h}$ and stimulated with LPS $(5 \mu \mathrm{g} / \mathrm{mL})$. At $4 \mathrm{~h}$ post LPS treatment, the cells were collected and the supernatants were evaluated for TNF- $\alpha$ level using a murine TNF- $\alpha$ ELISA kit from BD
Biosciences (San Jose, CA, USA) according to the manufacturer's instructions.

\section{Statistical analysis}

All data are represented as the mean \pm S.E.M of at least three independent experiments.. Statistical analyses were performed using SAS statistical software (SAS Institute, Cray, NC, USA) using one-way analysis of variance, followed by Dunnett's multiple range tests. $P$ values $<0.05$ was considered statistically significant.

\section{RESULTS}

\section{Effect of CCP extract on DPPH radical scavenging activity}

As shown in Fig. 1A, CCP extract exhibited significant DPPH radical- scavenging activity in a concentration-dependent manner showing a maximum effect at $1 \mathrm{mg} / \mathrm{mL}(p<0.001)$. The ESR spectroscopy data is represented in Fig $1 \mathrm{~B}$. The concentration required for 50 percent inhibition of DPPH free radicals was found to be at $0.08 \mu \mathrm{g} / \mathrm{mL}$.

\section{Effect of CCP extract on BV-2 cell viability}

Treatment with CCP extract at indicated concentrations $(10-100 \mathrm{mg} / \mathrm{mL})$ did not affect the overall cell viability nor did they exhibit any cytotoxicity on BV-2 microglia cells (Fig 2). This data indicate that the concentrations used in the study were safe to BV-2 microglial cells.

\section{CCP extract attenuates NO production in LPS-stimulated BV-2 cells}

Cells treated with LPS $(5 \mu \mathrm{g} / \mathrm{ml})$ alone significantly increased in NO levels $(p<0.001)$ as shown in Fig 3. Pre-treatment with CCP extract at indicated concentrations significantly and dose-dependently suppressed the excessive release of $\mathrm{NO}$ in $\mathrm{BV}-2$ cells (Fig. 3). The significant effect was observed at $10 \mu \mathrm{g} / \mathrm{ml}(p<$ 0.05 ) and maximum effect was observed at a concentration of $100 \mu \mathrm{g} / \mathrm{ml}(p<0.001)$.

\section{CCP extract attenuates iNOS expression in LPS-stimulated BV-2 cells}

Western blot analysis revealed that LPSstimulation to BV-2 microglia increased the protein expressional levels of iNOS (Fig 4). However, the increased expression of iNOS in LPS-stimulated BV-2 cells was suppressed when these cells were treated with CCP extract (40 and $80 \mu \mathrm{g} / \mathrm{mL}$ ). 
Effect of CCP extract on TNF- $\alpha$ production in LPS-stimulated BV-2 cells

As shown in Fig. 5, TNF- $\alpha$ levels increased significantly after LPS treatment $(5 \mu \mathrm{g} / \mathrm{mL})$ when compared to those in untreated cells $(p<0.001)$. However, CCP extract significantly inhibited TNF- $\alpha$ production in a concentration-dependent manner showing $p<0.05$ at $20 \mu \mathrm{g} / \mathrm{mL}, p<0.01$ at $40 \mu \mathrm{g} / \mathrm{mL}$ and $p<0.001$ at 80 and $100 \mu \mathrm{g} / \mathrm{mL}$ concentrations, respectively in LPS-stimulated BV-2 cells.

A

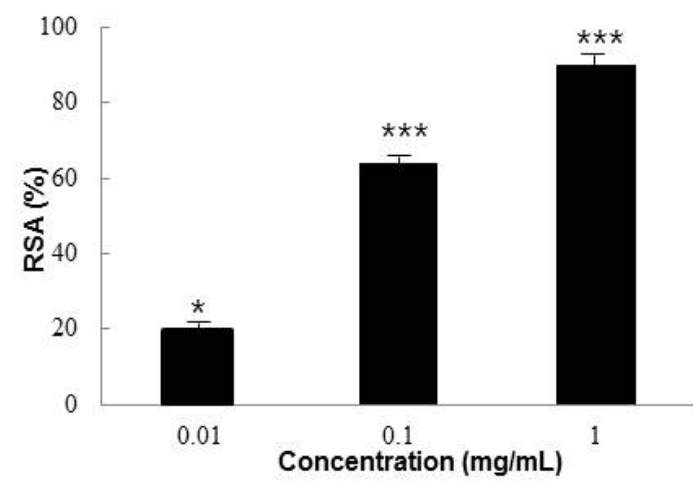

B

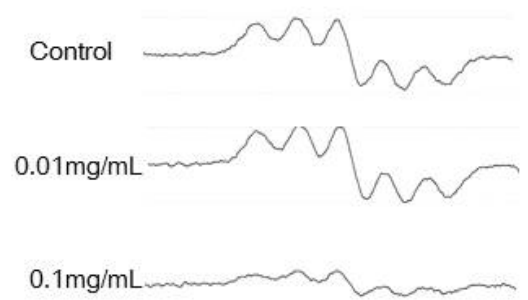

$1 \mathrm{mg} / \mathrm{mL}$

Fig 1: Effect of CCP extract on DPPH radicalscavenging activity (RSA). A: The capacity of CCP extract to scavenge DPPH radicals at various concentrations $(0.01,0.1$ and $1 \mathrm{mg} / \mathrm{mL}$ ) was shown. B: ESR spectral data. BV-2 cells were treated with or without CCP extract at the various concentrations $(0.01,0.1$ and $1 \mathrm{mg} / \mathrm{mL})$. The scavenging activity of each sample on DPPH radical was measured using a JES-FA ESR spectrometer. A spin adduct was measured on an ESR spectrometer exactly $2 \mathrm{~min}$ later. Data are presented as mean \pm SEM $(n=3)$ for three independent experiments; ${ }^{*} p<0.05$, and ${ }^{* * *} p<$ 0.001 , compared with control group

\section{DISCUSSION}

This report demonstrates that CCP extract markedly inhibits LPS-induced inflammatory responses in BV-2 microglial cell line. Neuroinflammation is characterized by the activation of microglia and expression of major inflammatory mediators in the CNS. Excessive production of inflammatory mediators, NO and proinflammatory cytokines from activated microglia has been implicated in inflammation mediated neurodegeneration. Evidence suggest that iNOS is the most important contributor to NO production in the brain after inflammatory assault [3]. Therefore inhibition of cytokine production in activated-microglia might serve as a key mechanism in the control of neuroinflammatory responses in neurodegeneration. In our study,

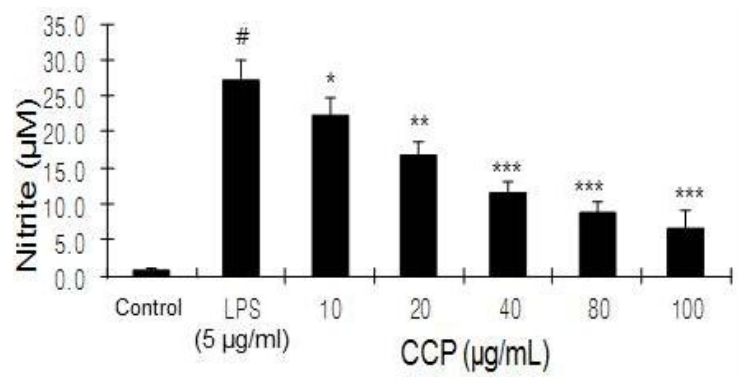

Fig 3: Effect of CCP extract on NO Production in LPSstimulated BV-2 microglial cells. BV-2 cells were treated with CCP extract at various concentrations (10, $20,40,80$ and $100 \mu \mathrm{g} / \mathrm{mL}$ ) with or without LPS (5 $\mu \mathrm{g} / \mathrm{mL}$ ) for $4 \mathrm{~h}$. The nitrite in the culture supernatant was evaluated using Griess reagent. Data are presented as the mean \pm SEM $(n=3)$ for three independent experiments. ${ }^{\#} p<0.001$, when compared with control group; ${ }^{*} p<0.05$, ${ }^{* *} p<0.01$ and ${ }^{* * *} p<$ 0.001 , when compared with only LPS-treated group (Note: CCP = Castenea cranata peel extract; LPS = lipopolysaccharide)

\section{BV-2 Cell}
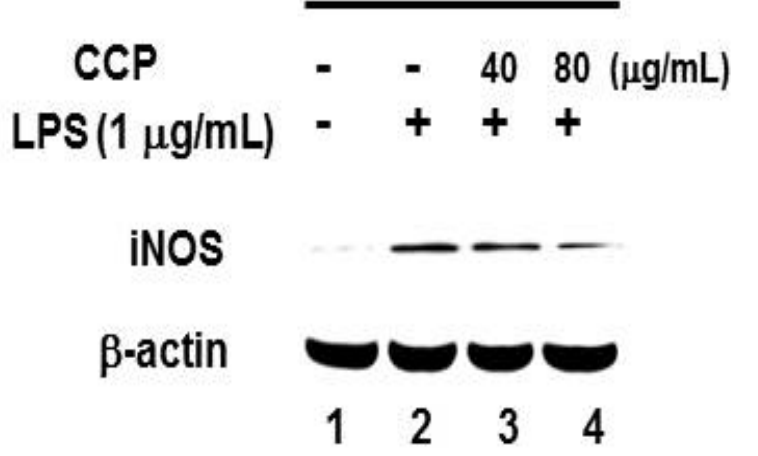

Fig 4: Effect of CCP extract on iNOS expressional levels in LPS-stimulated BV-2 microglial cells. The expression levels of iNOS production in the LPS (5 $\mu \mathrm{g} / \mathrm{mL}$ ) - stimulated BV-2 cells at two concentrations of the CCP extract ( 40 and $80 \mu \mathrm{g} / \mathrm{mL}$ ) was monitored by immunoblot analyses with the specific antibody against iNOS. The internal control used was $\beta$-actin. (Note: $\mathrm{CCP}=$ Castenea cranata; LPS = lipopolysaccharide; iNOS: Inducible nitric oxide) 


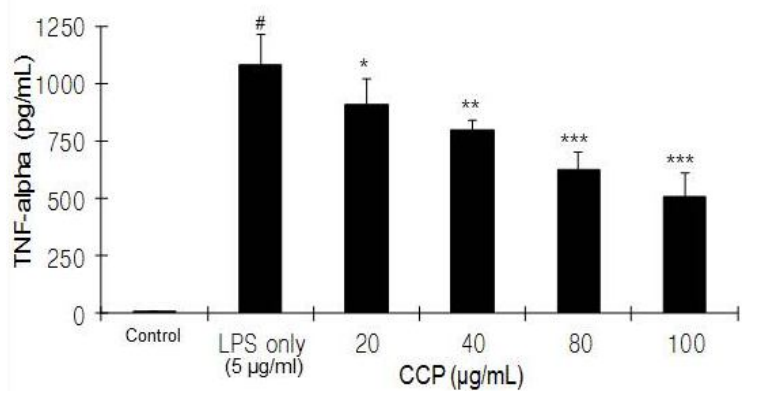

Fig 5: Effect of CCP extract on TNF-a production in LPS-stimulated BV-2 microglial cells. Suppression of pro-inflammatory cytokine TNF- $\alpha$ expression by CCP extract was measured with ELISA test. BV-2 cells were treated with CCP extract at 20, 40, 80 and 100 $\mu \mathrm{g} / \mathrm{mL}$ with or without LPS $(5 \mu \mathrm{g} / \mathrm{mL})$ for $4 \mathrm{~h}$. The TNF$\alpha$ in the culture supernatant was evaluated using a murine TNF- $\alpha$ ELISA kit. Data are presented as the mean \pm S.E.M. $(n=3)$ for three independent experiments. ${ }^{*} p<0.001$, when compared with control group; ${ }^{*} p<0.05,{ }^{* *} p<0.01$ and ${ }^{* * *} p<0.001$, when compared with LPS alone group (Note: CCP $=$ TNF- $\alpha$ $=$ tumor necrosis factor-alpha; LPS = lipopolysaccharide)

CCP extract significantly inhibited the LPSstimulated increase in $\mathrm{NO}$ production and suppressed the iNOS protein expression in LPSstimulated BV-2 cells.

Activated microglial cells are known to release several proinflammatory cytokines including TNF- $\alpha$ which may not only amplify the inflammatory cascade, but also cause inflammatory injury $[14,15]$. Our results indicate that CCP extract significantly suppressed the production of TNF- $\alpha$ in the LPS-activated BV-2 cells. Considering the data obtained we suggest that CCP extract might have a potent antineuroinflammatory activity via the inhibition of LPS-stimulated production of TNF- $\alpha, \mathrm{NO}$, as well as iNOS protein in microglia.

The mechanism of microglia-mediated neuroinflammation is partly attributed to release of reactive oxygen substances (ROS). Excessive production of ROS results in tissue injury by damaging macromolecules and lipid peroxidation of membranes. In addition, it propagates the release of inflammatory mediators responsible for the recruitment of additional neutrophils and macrophages in the CNS thereby hastening neuro-inflammation [16]. Thus free radicals are important mediators that provoke or sustain inflammatory responses and their neutralization by antioxidants and radical scavengers can reduce brain inflammation. It was well known that $\mathrm{DPPH}$ radical assay as one of the widely used methods for evaluating the free radical scavenging activities of several antioxidants [9]. Earlier reports revealed that CCP possessed strong antioxidant compounds $[17,18]$. It has been demonstrated that chestnut fruits contain several phenolic compounds [19]. The antioxidant compounds such as scoparone and scopoletin isolated from CCP are known to possess anti-oxidant properties and antiinflammatory activities [20-22]. CCP was reported to suppress the liver cytotoxicity induced by chronic ethanol administration due to its potent antioxidant effects $[17,18]$. Reports also revealed that CCP possess neuroprotective activity and anti-amnesic activities by attenuating the ROS and oxidative stress in neuronal cells [8]. In our present study, the CCP extract also exhibited significant free radical-scavenging effects indicating that CCP extract might contain potential antioxidant agents.

\section{CONCLUSION}

The present study reveals for the first time that CCP extract attenuates neuroinflammatory processes in LPS-induced BV-2 microglial cells. The anti-neuroinflammatory effects of CCP extract may be attributed to its regulatory effect on the release of pro-inflammatory cytokines, such as TNF- $\alpha$, and its strong antioxidant effect. Therefore, CCP extract should be explored as a therapeutic agent in the treatment of microgliamediated neuro-inflammatory disease.

\section{REFERENCES}

1. Nelson PT, Soma LA, Lavi E. Microglia in diseases of the central nervous system. Annal Med 2002; 34: 491500 .

2. Matsumoto $Y$, Ohmori K, Fujiwara M. Immune regulation by brain cells in the central nervous system:microglia but not astrocytes present myelin basic protein to encephalitogenic $T$ cells under in vivo mimicking conditions. Immunol 1992; 76: 209-216.

3. Gao HM, Jiang J, Wilson B, Zhang W, Hong JS, Liu B. Microglial activation-mediated delayed and progressive degeneration of rat nigral dopaminergic neurons: relevance to Parkinson's disease. J Neurochem 2002; 81: 1285-1297.

4. Kim SH, Smith CJ, Van Eldik LJ. Importance of MAPK pathways for microglial pro-inflammatory cytokine IL$1 \beta$ production. Neurobiol Aging 2004a; 25: 431-439.

5. Park TK, Koppula S, Kim MS, Jung SH, Kang H. AntiNeuroinflammatory Effects of Houttuynia cordata Extract on LPS-Stimulated BV-2 Microglia. Trop J Pharm Res 2013; 12: 523-528.

6. Mizutani T, Shizuka F, Matsuzawa T, Amano Y, Arikawa Y. Anti-glycation activity of Japanese Chestnut (Castanea crenata) inner skin extract is beneficial for 
Type 2 Diabetes in a rat model. Anti-Aging Med 2014; 10: $112-119$

7. Jeong $H R$, Jo $Y N$, Jeong JH, Jin DE, Song BG, Choi SJ, Shin DH, Heo1 HJ. Antiamnesic effects of ethyl acetate fraction from Chestnut (Castanea crenata var. dulcis) inner skin on Ab 25-35-induced cognitive deficits in mice. J Med Food 2012; 15: 1051-1056.

8. Huh Z. Tang-aek. In: Huh, Z. (Ed.), Dong-Eu-Bo-Gam (1613). Namsandang, Seoul. 1966; $p 1160$.

9. Kang H, Koppula S, Park TK. Salicornia bigelovii Torr attenuates neuro-inflammatory responses in lipopolysaccharide-induced $B V-2$ microglia by regulation of NF-kappa B signaling. Trop $J$ Pharm Res 2013; 12 (6): 897-903.

10. Park TK, Koppula S, Kim MS, Jung SH, Kang H. Antineuroinflammatory effects of Houttuynia cordata extract on LPS-stimulated BV-2 microglia. Trop $J$ Pharm Res 2013; 12 (4): 523-528.

11. Kim MS, Koppula S, Jung SH, Kim JY, Lee HR, Lee SR, Park YD, Lee KE, Park TK, Kang H. Olea europaea Linn (Oleaceae) fruit pulp extract exhibits potent antioxidant activity and attenuates neuroinflammatory responses in lipopolysaccharide- stimulated microglial cells. Trop J Pharm Res 2013; 12 (3): 357362.

12. Nanjo $F$, Goto $K$, Seto $R$, Suzuki M. Scavenging effects of tea catechins and their derivatives on 1,1-diphenyl2-picrylhydrazyl radical. Free Radic Biol Med 1996; 21: 895-902.

13. *****

14. Frankola KA, Greig NH, Luo W, Tweedie D. Targeting TNF-alpha to elucidate and ameliorate neuroinflammation in neurodegenerative diseases. CNS Neurol Disord Drug Targets 2011; 10: 391-403.
15. Perry RT, Collins JS, Wiener H, Acton R, Go R.C. The role of TNF and its receptors in Alzheimer's disease. Neurobiol Aging 2001; 22: 873-883.

16. Conforti F, Sosa S, Marrelli M, Menichini F, Statti GA, Uzunov $D$, Tubaro A, Menichini $F$, Loggia RD. In vivo anti-inflammatory and in vitro antioxidant activities of Mediterranean dietary plants. J Ethnopharmacol 2008; 116: 144-151.

17. Noh JR, Gang GT, Kim YH, Yang KJ, Hwang JH, Lee HS, Oh WK, Song KS, Lee CH. Antioxidant effects of the chestnut (Castanea crenata) inner shell extract in t-BHP-treated HepG2 cells, and CC/4- and high-fat diet-treated mice. Food Chem Toxicol 2010; 48: 3177-3183.

18. Noh JR, Kim YH, Gang GT, Hwang JH, Lee HS, Ly SY, Oh WK, Song KS, Lee CH. Hepatoprotective effects of chestnut (Castanea crenata) inner shell extract against chronic ethanol-induced oxidative stress in C57BL/6 mice. Food Chem Toxicol 2011; 49: 15371543.

19. Ribeir $O B$, Rangel J, Valentao $P$, Andrade $P B$, Pereira $J A$, Bolke $H$, Seabra RM. Organic acids in two portuguese chestnut (Castanea sativa Miller) varieties. Food Chem. 2007; 100: 504-508.

20. Sourivong $P$, Schronerova K, Babincova M. Scoparone inhibits ultraviolet radiation-induced lipid peroxidation. Z. Naturforsch C 2007; 62: 61-64.

21. Panda S, Kar A. Evaluation of the antithyroid, antioxidative and antihyperglycemic activity of scopoletin from Aegle marmelos leaves in hyperthyroid rats. Phytother Res 2006; 20: 11031105.

22. Ding Z, Dai Y, Hao H, Pan R, Yao X, Wang Z. AntiInflammatory effects of Scopoletin and underlying mechanisms. Pharm Biol 2008; 46: 854-860. 